\title{
Implementasi Peraturan Presiden Nomor 87 Tahun 2017 Tentang Penguatan Pendidikan Karakter (PPK)
}

\author{
Suanto ${ }^{\mathrm{a}, 1 *}$, Nurdiyana $^{\mathrm{b}, 2}$ \\ ${ }^{a, b}$ Program Studi Pendidikan Pancasila dan Kewarganegaraan, Fakultas Keguruan dan Ilmu Pendidikan \\ Universitas Pamulang \\ ${ }^{1}$ dosen02190@unpam.ac.id; ${ }^{2}$ dosen02080@unpam.ac.id; \\ *korespondensi penulis
}

Naskah diterima: 28 Agustus 2020, direvisi: 18 September 2020, disetujui: 27 September 2020

\begin{abstract}
Abstrak
Pendidikan karakter pada satuan pendidikan formal menjadi suatu hal yang sangat penting hal ini tertulis dalam Peraturan Presiden Nomor 87 Tahun 2017 tentang Penguatan Pendidikan Karakter (PPK), akan tetapi bagaimana implementasi kebijakan dan pengintegrasiannya dalam kurikulum serta dampak pendidikan karakter bagi siswa dalam satuan pendidikan masih perlu dimonitoring dan dievaluasi implementasinya. Atas dasar latar belakang tersebut maka tujuan dari penelitian ini yaitu untuk menganalisis data secara empiris tentang implementasi Peraturan Presiden Nomor 87 Tahun 2017 tentang Penguatan Pendidikan Karakter (PPK) di SMK Letris Indonesia. Jenis Penelitian yang digunakan yaitu Penelitian Normatif Empiris dengan menggunakan metode kualitatif, dengan teknik pengumpulan data menggunakan angket, studi dokumen, observasi, dan wawancara, dengan responden yang terdiri dari kepala sekolah, guru, dan siswa. Hasil penelitian menunjukan bahwa sekolah telah mengimplementasikan dan mengintegrasikan kebijakan PPK yang terlihat dari prinsip pelaksanaan PPK sebagaimana telah diatur pada Pasal 5, dan Penyelenggaraan PPK yang sesuai dengan Pasal 6 ayat 1 Peraturan Presiden Nomor 87 Tahun 2017 tentang Penguatan Pendidikan Karakter (PPK). Dengan demikian dapat disimpulkan bahwa implementasi kebijakan PPK telah sesuai dengan perpres tersebut, namun masih perlu dievaluasi secara berkala pengintegrasiannya dalam proses belajar mengajar dan dampaknya bagi siswa.
\end{abstract}

Kata-kata kunci: Implementasi; Peraturan Presiden Nomor 87 Tahun 2017

\section{Abstract}

Character education in formal education units is very important, this is written in Presidential Regulation Number 87 of 2017 concerning Strengthening Character Education (PPK), however, how to implement policies and integrate them in the curriculum and the impact of character education for students in educational units still needs monitored and evaluated its implementation. On the basis of this background, the purpose of this study is to analyze data empirically on the implementation of Presidential Regulation Number 87 of 2017 concerning Strengthening Character Education (PPK) at SMK Letris Indonesia. The type of research used is Normative Empirical Research using qualitative methods, with data collection techniques using questionnaires, document study, observation, and interviews, with respondents consisting of principals, teachers, and students. The results of the study show that schools have implemented and integrated PPK policies as seen from the principles of implementing PPK as regulated in Article 5, and the implementation of PPK in accordance with Article 6 paragraph 1 of Presidential Regulation Number 87 of 2017 concerning Strengthening Character Education (PPK). Thus it can be concluded that the implementation of the $P P K$ policy is in accordance with the Perpres, but it still needs to be evaluated periodically for its integration in the teaching and learning process and its impact on students.

Keywords: Implementation; Presidential Regulation Number 87 of 2017 


\section{Pendahuluan}

Karakter merupakan pondasi utama dalam kehidupan serta kemajuan suatu bangsa, menurut Thomas Lickona (Gunawan, 2012:23) menyatakan bahwa pendidikan karakter yaitu membentuk kepribadian seseorang melalui pendidikan budi pekerti, yang hasilnya terlihat dalam tindakan nyata seseorang, yaitu tingkah laku yang jujur, baik, bertanggung jawab, menghormati hak orang lain, kerja keras dan sebagainya. Sedangkan T. Ramli (dalam Gunawan, 2012:23) mendefinisikan bahwa "pendidikan karakter memiliki esensi dan makna yang sama dengan pendidikan moral dan pendidikan akhlak. Tujuannya adalah membentuk pribadi anak, supaya menjadi manusia yang baik, warga masyarakat yang baik, dan warga negara yang baik bagi suatu masyarakat atau bangsa". Dari kedua pendapat tersebut dapat disimpulkan bahwa pendidikan karakter mengarah kepada pendidikan moral serta akhlak yang pada akhirnya nanti akan terlihat pada sikap serta tingkah laku di masyarakat.

Sementara itu Russel William sebagaimana dikutip Muchlas Samani (2012:44-45) mengumpamakan karakter itu ibarat "otot", dimana otot itu semakin dilatih akan semakin kuat sementara jika tidak dilatih makan otot-otot tersebut tidak akan berkembang. Melalui berbagai latihan maka otot-otot dalam hal ini adalah karakter akan menjadi kuat dan bila dilakukan dengan berkesinambungan tentu dapat menjadi suatu kebiasaan. Dapat kita simpulkan bahwa setiap orang yang berkarakter akan selalu melakukan hal yang baik karena memang mereka mencintai kebaikan (loving the good). Atas dasar itulah akan mendorong niat untuk selalu melakukan perbuatan dan hal yang baik, baik untuk diri sendiri maupun untuk lingkungannya. Sementara itu menurut Alfie Kohn seorang penulis dan dosen berpendapat bahwa pendidikan karakter dapat berikan definisi secara luas dan sempit, dimana dalam pengertian yang luas dapat diartikan bahwa pendidikan karakter meliputi keseluruhan usaha yang dilakukan oleh sekolah di luar bidang formal yaitu tujuan pendidikan karakter yaitu untuk membentuk peserta didik berkembang menjadi pribadi yang berkarakter baik. Sementara itu, dalam pengertian yang sempit, dimana pendidikan karakter didefinisikan sebagai wadah melatih moral untuk mengaktualisasikan nilai-nilai yang baik.

Sesungguhnya pendidikan karakter telah ada sejak pendidikan itu ada, karena pada hakikatnya pendidikan adalah pembiasaan pada perilaku baik dan menghindari perilaku buruk. Banyak sekali perilaku baik dan buruk yang ada di dalam kehidupan manusia, namun hasil kajian Pusat Kurikulum Kemdikbud (2009: 910) teridentifikasi 18 nilai yang berasal dari agama, Pancasila, budaya, serta tujuan pendidikan nasional, yakni: (1) religius, (2) jujur, (3) toleransi, (4) disiplin, (5) kerja keras, (6) Kreatif, (7) Mandiri, (8) Demokratis, (9) Rasa Ingin Tahu, (10) Semangat Kebangsaan, (11) Cinta Tanah Air, (12) Menghargai Prestasi, (13) Bersahabat/ Komunikatif, (14) Cinta Damai, (15) Gemar Membaca, (16) Peduli Lingkungan, (17) Peduli Sosial, \& (18) Tanggung Jawab.

Melihat sangat pentingnya pengembangan terhadap karakter, Pemerintah Indonesia merumuskan tujuan pendidikan nasional yang terdapat dalam Undang-Undang Nomor 20 tahun 2003 tentang Sistem Pendidikan Nasional yang menjelaskan bahwa: pendidikan nasional berfungsi mengembangkan kemampuan dan membentuk watak serta peradaban bangsa yang bermartabat dalam rangka mencerdaskan kehidupan bangsa, bertujuan untuk berkembangnya potensi peserta didik agar menjadi manusia yang beriman dan bertakwa kepada Tuhan Yang Maha Esa, berakhlak mulia, sehat, berilmu, cakap, kreatif, 
mandiri dan menjadi warga negara yang demokratis serta bertanggung jawab. (Kemendikbud, 2003).

Sesuai dengan tujuan tersebut dan dalam rangka membentuk karakter bangsa, maka dibuatlah Peraturan Presiden Nomor 87 Tahun 2017 tentang Penguatan Pendidikan Karakter (PPK). Di dalam peraturan tersebut antara lain dinyatakan bahwa: penguatan pendidikan karakter adalah gerakan pendidikan di bawah tanggung jawab satuan pendidikan untuk memperkuat karakter peserta didik melalui harmonisasi olah hati, olah rasa, olah pikir, dan olah raga dengan pelibatan dan kerja sama antara satuan pendidikan, keluarga, dan masyarakat sebagai bagian dari Gerakan Nasional Revolusi Mental (GNRM). Dalam Perpres Nomor 87 tahun 2017 tersebut dijelaskan juga pada Pasal 6 ayat 4 yaitu "Penyelenggaraan PPK pada Satuan Pendidikan jalur Pendidikan Formal dengan prinsip manajemen berbasis sekolah/madrasah sebagaimana dimaksud pada ayat (3) merupakan tanggung jawab kepala satuan Pendidikan Formal dan guru" (Peraturan Presiden, 2017)

Kemudian

untuk dapat mengimplementasikan pasal 6 ayat 4 dan Pasal 14 Perpres Nomor 87 Tahun 2017 tersebut ditetapkanlah Permendikbud Nomor 20 tahun 2018 tentang Penguatan Pendidikan Karakter pada Satuan Pendidikan Formal. Pada pasal 1 ayat 2 diterangkan bahwa "Satuan Pendidikan Formal, yang selanjutnya disebut Sekolah adalah kelompok layanan pendidikan yang menyelenggarakan pendidikan formal, terstruktur dan berjenjang, terdiri atas taman kanak-kanak (TK), satuan pendidikan jenjang pendidikan dasar, dan satuan pendidikan jenjang pendidikan menengah" (Peraturan Presiden, 2017)

Berdasarkan pada kebijakan tentang penyelenggaraan PPK tersebut maka yang menjadi fokus utamanya adalah bagaimana implementasinya dalam satuan pendidikan formal dalam hal ini yaitu jenjang pendidikan menengah, implementasi menjadi suatu hal yang sangat penting karena Gerakan PPK, pada dasarnya tidak bersifat kaku dengan demikian dapat di terintegrasikan dalam susunan kurikulum, dengan berpedoman pada prinsip pelaksanaan PPK yang tertuang dalam pasal 5 Perpres Nomor 87 tahun 2017 yaitu "1). berorientasi pada berkembangnya potensi Peserta Didik secara menyeluruh dan terpadu, 2). keteladanan dalam penerapan pendidikan karakter pada masing-masing lingkungan pendidikan, dan 3). berlangsung melalui pembiasaan dan sepanjang waktu dalam kehidupan sehari-hari”.

Nilai utama karakter yang terdapat pada konsep PPK dapat dikembangkan dan diimplementasikan dalam setiap materi pelajaran, muatan lokal, maupun pengelolaan kelas. Dengan tujuan akhir dapat mengembangkan dan menguatkan karakter para siswa. Dari uraian tersebut pendidikan karakter yang terdapat dalam satuan pendidikan formal menjadi suatu hal yang sangat penting, akan tetapi bagaimana implementasi kebijakan dan pengintegrasiannya dalam kurikulum serta dampak pendidikan karakter bagi siswa dalam satuan pendidikan masih perlu dimonitoring dan dievaluasi implementasinya.

Atas dasar latar belakang permasalahan tersebut maka penelitian ini dilaksanakan dengan tujuan untuk menganalisis data-data secara empiris mengenai implementasi Perpres Nomor 87 tahun 2017 tentang Penguatan Pendidikan Karakter (PPK) di SMK Letris Indonesia 2. Penelitian ini penting guna mengetahui sejauh mana implementasi dari Perpres Nomor 87 tahun 2017 diterapkan atau tidaknya dalam satuan pendidikan formal khususnya pendidikan menengah. 
Jurnal Pendidikan Kewarganegaraan

Vol. 7 No. 2 September 2020

\section{Metode}

Jenis Penelitian yang dilaksanakan yaitu Penelitian Normatif Empiris dengan menggunakan metode kualitatif, penelitian hukum normatif empiris ini pada prinsipnya adalah gabungan antara pendekatan hukum normatif yang kemudian didukung oleh unsurunsur empiris.

Pelaksanaan penelitian bertempat di SMK Letris Indonesia 2 yang beralamat di Jln. Raya Siliwangi Nomor. 55 Kelurahan Pondok Benda, Kecamatan Pamulang, Kota Tangerang Selatan, Provinsi Banten. Sebagai satuan pendidikan formal SMK Letris Indonesia 2 memiliki kewajiban dalam melaksanakan atau mengimplementasikan kebijakan tentang PPK. Lokasi penelitian dipilih karena akses dan keterjangkauan dalam melakukan penelitian.

Teknik pengumpulan dan analisis data yang dilakukan, yaitu dengan menggunakan angket, studi dokumen, observasi, dan wawancara. Dengan responden Kepala Sekolah, Guru, dan Siswa. Selanjutnya, data yang sudah terkumpul akan dianalisis secara deskriptif.

\section{Hasil dan Pembahasan}

Berdasarkan hasil wawancara yang dilakukan pada kepala sekolah, dan guru serta kuesioner siswa tentang Implementasi dari Peraturan Presiden Nomor 87 tahun 2017 tentang Penguatan Pendidikan Karakter (PPK) di SMK Letris Indonesia 2 diperoleh data sebagaimana uraian berikut ini.

\section{Prinsip Pelaksanaan PPK}

Pelaksanaan PPK di SMK Letris Indonesia 2 dalam pengimplementasiannya menggunakan prinsip pelaksanaan PPK sebagaimana telah diatur pada Pasal 5, yakni PPK diselenggarakan dengan mengacu pada prinsip berikut ini;
1. Prinsip berorientasi pada berkembangnya potensi Peserta didik secara menyeluruh dan terpadu

Dalam pengimplementasiannya, sekolah tidak hanya menyusun program pengembangan akademik melainkan juga mengembangkan dan meningkatkan program non akademik untuk memfasilitasi potensi-potensi siswa. Hal tersebut dapat terlihat dalam berbagai bentuk kegiatan siswa yang menjadi bagian dalam program kerja yang disusun oleh wakil kepala sekolah bidang kesiswaan. Hal tersebut dapat terlihat berdasarkan hasil survey terhadap 68 siswa, sebanyak 62 siswa menyatakan terdapat program atau kegiatan yang bertujuan pada pengembangan potensi peserta didik seperti mengadakan dan mengikutsertakan peserta didik dalam perlombaan di bidang akademik maupun non akademik, baik internal maupun eksternal.

\section{Pertanyaan:}

Apakah ada kebiasaan bulanan /semester/ tahunan, seperti lomba, pemberian hadiah bagi yang berprestasi, pemberian motivasi, kunjungan rumah, dan sebagainya.

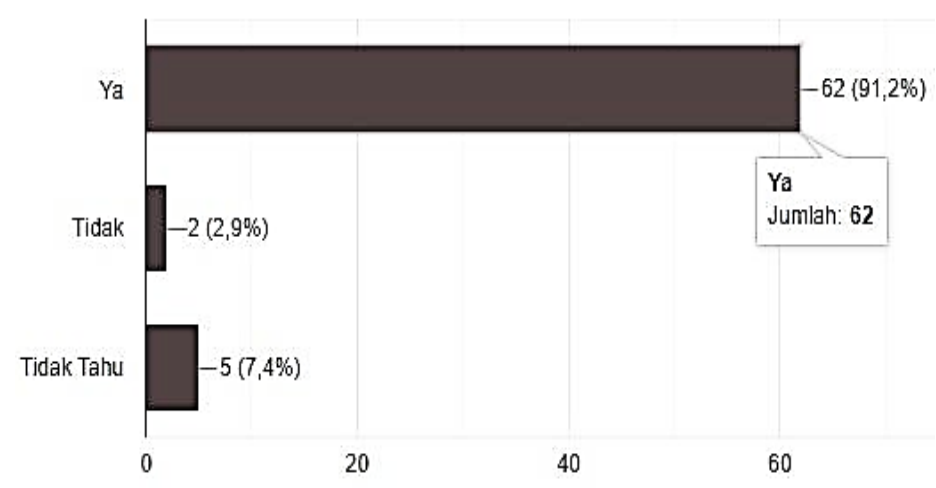

Sumber: data penelitian, 2020

Gambar 1. Hasil survei siswa mengenai pengembangan potensi 
2. Prinsip keteladanan dalam penerapan pendidikan karakter pada masing-masing lingkungan pendidikan

Dalam pengimplementasiannya, sekolah telah membuat kode etik pendidik dan tenaga pendidik dalam hal berpakaian dan bersikap. Hal ini dilakukan untuk memberikan keteladanan kepada siswa. Hal tersebut dapat terlihat berdasarkan hasil survey terhadap 68 siswa, sebanyak 67 siswa menyatakan terdapat keteladanan pendidik dan tenaga kependidikan.

Pertanyaan:

Apakah Bapak/Ibu guru memberikan keteladanan dalam berbusana, berhias, berperilaku keramahan, tepat waktu, tidak merokok.

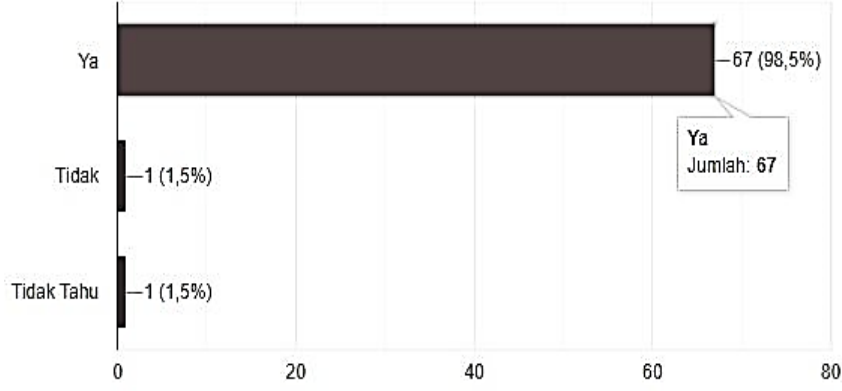

Sumber: data penelitian, 2020

Gambar 2. Hasil survei siswa mengenai keteladanan pendidik dan tenaga kependidikan

3. Prinsip berlangsung melalui pembiasaan dan sepanjang waktu dalam kehidupan sehari-hari

Dalam pengimplementasiannya, sekolah melaksanakan pembiasaan-pembiasaan yang sesuai dengan nilai-nilai karakter. Sesuai dengan nilai karakter yang terdapat dalam pasal 3, yakni "nilai-nilai religius, jujur, toleran, disiplin, bekerja keras, kreatif mandiri, demokratis, rasa ingin tahu, semangat kebangsaan, cinta tanah air, menghargai prestasi, komunikatif, cinta damai, gemar membaca, peduli lingkungan, peduli sosial, dan bertanggung jawab". Hal tersebut dapat terlihat berdasarkan hasil survey terhadap 68 siswa, sebanyak 67 siswa menyatakan terdapat kebiasaan di lingkungan Sekolah yang sesuai dengan nilai karakter.

Pertanyaan:

Apakah ada kegiatan nilai karakter mingguan, seperti: sholat Jum'at di sekolah, pembacaan Yasin, dan sebagainya.

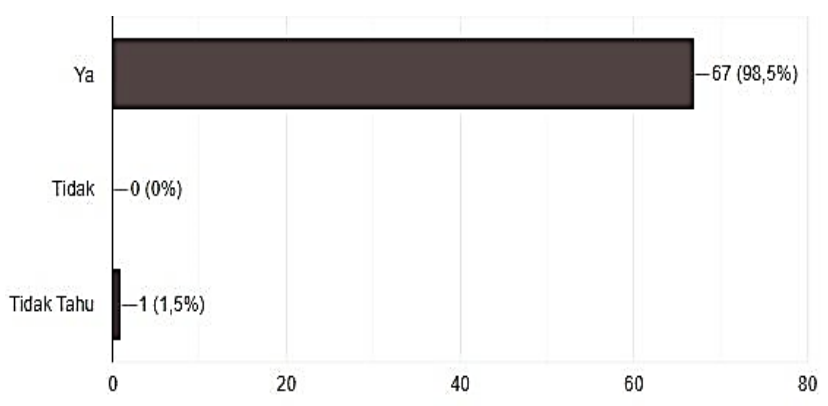

Sumber: data penelitian, 2020

Gambar 3. Hasil survei siswa mengenai Pembiasaan

\section{Penyelenggaraan PPK}

Implementasi Penyelenggaraan PPK, 80 Pasal 6 ayat 1 Peraturan Presiden Nomor 87 Tahun 2017 Tentang Penguatan Pendidikan Karakter (PPK) yaitu:

1. Intrakurikuler

Berdasarkan penjelasan pada pasal 7 ayat 1, yaitu: penyelenggaraan PPK dalam kegiatan Intrakurikuler sebagaimana dimaksud dalam Pasal 6 ayat (1) huruf a merupakan penguatan nilai-nilai karakter melalui kegiatan penguatan materi pembelajaran, metode pembelajaran sesuai dengan muatan kurikulum berdasarkan ketentuan peraturan perundang-undangan.

Dalam implementasinya guru mata pelajaran mengintegrasikan nilai karakter dalam mata pelajaran yang diampunya dengan terlebih dahulu melakukan perencanaan pembelajaran, kemudian kegiatan belajar mengajar, dan mengevaluasi kegiatan belajar mengajar. Pengintegrasian tersebut dapat 
terlihat dalam RPP (Rencana Pelaksanaan Pembelajaran) yang dibuat oleh setiap guru. Hal ini diketahui dari hasil wawancara dengan guru pengampu mata pelajaran PPKn.

\section{Kokurikuler}

Berdasarkan penjelasan pada pasal 7 ayat 2, "Penyelenggaraan PPK dalam kegiatan kokurikuler sebagaimana dimaksud dalam Pasal 6 ayat (1) huruf b merupakan penguatan nilai-nilai karakter yang dilaksanakan untuk pendalaman dan/ atau pengayaan kegiatan Intrakurikuler sesuai muatan kurikulum".

Dalam implementasinya, sekolah melalui Kepala Sekolah, Wakil Kepala Sekolah, dan Guru menyusun dan melaksanakan program atau kegiatan yang bersifat kokurikuler guna membantu kegiatan yang bersifat intrakurikuler telah terlaksana di dalam lingkungan sekolah dengan mengadakan beberapa kegiatan luar sekolah seperti mengunjungi museum dan tempat-tempat edukasi lain yang dilaksanakan secara berkelanjutan dan terintegrasi dengan mata pelajaran.

\section{Ekstrakurikuler}

Berdasarkan penjelasan pada pasal 7 ayat 3, Penyelenggaraan PPK dalam kegiatan Ekstrakurikuler sebagaimana dimaksud dalam Pasal 6 ayat (1) huruf c merupakan penguatan nilai-nilai karakter dalam rangka perluasan potensi, bakat, minat, kemampuan, kepribadian, kerja sama, dan kemandirian Peserta Didik secara optimal.

Dalam implementasinya, kegiatan ekstrakurikuler dilaksanakan dalam bentuk kegiatan kepramukaan, paskibra, kesenian, dan kerohanian serta kegiatan lainnya yang dapat menjadi media siswa untuk mengembangkan potensi, minat dan bakat.

\section{Kesimpulan}

Melihat berbagai indikator yang terdapat pada SMK Letris Indonesia 2 tentang Implementasi Peraturan Presiden Nomor 87 Tahun 2017 Tentang Penguatan Pendidikan Karakter (PPK), secara khusus sesuai isi pasal 5 mengenai tiga prinsip utama PPK yaitu "berorientasi pada berkembangnya potensi peserta didik secara menyeluruh dan terpadu; keteladanan dalam penerapan pendidikan karakter pada masing-masing lingkungan pendidikan; dan berlangsung melalui pembiasaan dan sepanjang waktu dalam kehidupan sehari-hari". Dengan demikian implementasi PPK dapat dilaksanakan diberbagai bidang. SMK letris indonesia 2 telah menyusun kebijakan kurikulum tingkat satuan pendidikan dengan berpegang teguh pada prinsip-prinsip tersebut.

Kemudian dalam pelaksanaan PPK pada Satuan pendidikan formal sesuai dengan pasal 6 ayat 1 , yang berisi tentang integrasi kegiatan intrakurikuler, kurikuler, dan ekstrakurikuler. SMK Letris Indonesia 2 mengimplementasikannya dalam rangkaian kegiatan sekolah mulai dari perencanaan sampai dengan pelaksanaan pembelajaran di dalam kelas yang kemudian didukung dengan aktualisasi di lapangan, serta pengembangan kompetensi siswa melalui kegiatan-kegiatan non akademik yang menjadi bagian dari kegiatan ekstrakurikuler wajib atau yang lebih bersifat pada pengembangan minat siswa dan pengembangan potensi diri.

\section{Referensi}

Gunawan, H. 2012. Pendidikan Karakter, Konsep dan Implementasi, Jakarta : Prenada Media Group.

Pusat Kurikulum Kemdikbud, 2009. Pengembangan dan Pendidikan Budaya \& Karakter Bangsa. Jakarta 
Jurnal Pendidikan Kewarganegaraan

Vol. 7 No. 2 September 2020

Kemendikbud. 2003. Undang-Undang No. 20

Tahun 2003 Tentang Sistem Pendidikan Nasional

Peraturan Presiden Republik Indonesia No. 87

Tahun 2017 tentang Penguatan

Pendidikan Karakter
Journal of Civics and Education Studies p-ISSN 2302-0865 | e-ISSN 2621-346X

Peraturan Menteri Pendidikan dan Kebudayaan No. 20 Tahun 2018 tentang Penguatan Pendidikan Karakter pada Satuan Pendidikan Formal 
Jurnal Pendidikan Kewarganegaraan

Vol. 7 No. 2 September 2020
Journal of Civics and Education Studies p-ISSN 2302-0865 | e-ISSN 2621-346X

\{Halaman ini sengaja dikosongkan\} 